\title{
The Financial Implications of the UNE-Platform: REVIEW OF THE EVIDENCE
}

\author{
T. Randolph Beard, PhD, George S. Ford, PhD, and Christopher C. Klein, PhD*
}

\section{INTRODUCTION}

The primary purpose of the Telecommunications Act of 1996' ("1996 Act") was to promote competition in the local exchange telecommunications marketplace - the last vestige of the telecommunications monopoly. ${ }^{2}$ Congress aimed to alter the competitive landscape of local telecommunications by splitting the integrated local phone market into its wholesale and retail components. ${ }^{3}$ In the post-1996 Act environment, firms seeking to offer retail local telephone services need not construct a local exchange network, but may offer services by acquiring the necessary facilities in a wholesale market where such facilities are bought and sold.

When the 1996 Act was signed into law in February 1996, however, the only firms capable of supplying the wholesale market in each local mar-

* An earlier version of this paper appeared as Bell Companies as Profitable Wholesale Firms: The Financial Implications of UNE-P, at http://www.phoenix-center.org (Nov. 2002). The estimation methodology has changed significantly from the earlier version, and follows George S. Ford, The Myth of Below Cost UNE-P Prices, at http://www.telepolicy.com (unpublished manuscript) (Feb. 2003). T. Randolph Beard is Professor of Economics at Auburn University; George S. Ford is Chief Economist at Z-Tel Communications; and Christopher C. Klein is Professor of Economics at Middle Tennessee State University, Murfreesboro, Tenn. and is former Chief Economist for the Tennessee Regulatory Authority. We thank Larry Spiwak for helpful comments and for assistance in preparing the manuscript for publication, and Bob Loube for his comments and recommendations arising out of his careful review of our calculations. Any remaining errors are the responsibility of the authors.

1 Telecommunications Act of 1996, Pub. L. No. 104-104, 110 Stat. 56 (codified as amended in scattered sections of 47 U.S.C.).

2 See H. R. ReP. No. 104-458, at 1 (1996).

3 See Verizon Communications Inc. v. FCC, 535 U.S. 467 (2002). "Congress ... aim [ed] to . . . reorganize markets." $I d$. at 489 . "[W] holesale markets for companies engaged in resale, leasing, or interconnection of facilities cannot be cre ated without addressing rates." Id. at 492. "The Act . . favor [ed] ... novel ratesetting designed to give aspiring com- ket were the incumbent local exchange carriers, or "ILECs." A similar situation persists today. Consequently, the wholesale prices of these wholesale monopolists were to be regulated and based on "cost," ${ }^{4}$ defined by the Federal Communications Commissions ("FCC") as total element long run incremental cost ("TELRIC"). ${ }^{5}$

While the FCC defined the cost standard, the state regulatory commissions were assigned the task of implementing the standard. ${ }^{6}$ Wholesale prices for unbundled network elements ("UNEs") - that is, the network facilities retail providers "buy" from the ILEC-have been and continue to be determined in evidentiary hearings before each state's respective regulatory commission. ${ }^{7}$

The 1996 Act has led to increased competition in many local telecommunications markets,

petitors every possible incentive to enter local retail telephone markets." Id. at 489. For a full discussion of the opinion and current FCC broadband initiatives, see Lawrence J. Spiwak, The Telecoms Twilight Zone: Navigating the Legal Morass Among the Supreme Court, the D.C. Circuit and the Federal Communications Commission, at http://www.phoenix-center.org/ pcpp/PCPP13Final.pdf (Aug. 2002); Lawrence J. Spiwak, Opinion: U.S. Competition Policy-The Four Horsemen of the Broadband Apocalypse, athttp://www.phoenix-center.org/commentaries/CWIHorsemen.pdf (Apr. 1, 2002).

4 The Telecommunications Act of $1996 \$ 252$ (d) (1) (stating that the "rate for the interconnection of facilities and equipment ... shall be based on the cost ... of providing the interconnection or network element ....").

5 In re Implementation of the Local Competition Provisions in the Telecommunications Act of 1996, First Report $\mathcal{E}^{\circ}$ Order, 11 FCC Rcd. 15499, 15515 (1996) [hereinafter Section 251 Order].

$6 \quad I d$ at para. 29 ("The 1996 Act requires the States to set prices for interconnection and unbundled elements that are cost-based, nondiscriminatory, and may include a reasonable profit.").

7 Letter from Joan Smith and Robert Nelson, Chair and Co-Vice Chair of the Telecommunications Committee of the National Association of Regulatory Utility Commissioners, to Sen. Thomas Daschle, Senate Majority Leader (Sept. 27, 2002) (on file with authors). 
though generally not to the extent many had hoped. ${ }^{8}$ Today, the combination of unbundled elements called "UNE-P" or "UNE-Platform"-a combination of unbundled loops, switching, transport and signaling-is the most successful mode of competitive entry created by the 1996 Act, and its growth substantially exceeds the alternative modes of entry. ${ }^{9}$ This success has brought UNE-P under a multifaceted attack by the Bell Operating Companies ("BOCs"). ${ }^{10}$

First, the BOCs argue that UNE-P deters Competitive Local Exchange Carrier ("CLEC") invest-

8 Yochi J. Dreazen, Telecom Crisis Forces FCC Shift; Could Let a Bell Buy WorldCom, WALL ST. J., July 15, 2002, at A1.

9 Pace Coalition, The UNE-P Fact Report 1-2, at http:/ /www.pacecoalition.org (Jan. 2003).

10 See, e.g., SBC CEO at FCC to Fight UNE Platform, TRDAILY, Sept. 6, 2002, at 2-3; Blaming High UNE Rates, ATE'T Says it. Will Avoid Florida, TRDAILy, Sept. 10, 2002, at 7-8; SBC Urges FCC to 'Clarify' TELRIC in Pending Arbitration, TRDAILY, Sept. 11, 2002, at 3-4; House Letter Rekindles Debate Over UNE Pricing, TRDAILY, Sept. 13, 2002, at 2; USTA's McCormick Removes Gloves in UNE-P, TELRIC Debate, TRDAILY, Sept. 13, 2002, at 3; SBC's Daley Weighs In On UNE Issue, TRDAILY, Sept. 17, 2002, at 3-4; Martin Opposes Seeking High Court Review of UNE Ruling, TRDAILY, Sept. 18, 2002, at 5; ATE'T Issues Economic Study to Bolster UNE Arguments, TRDAILY, Sept. 18, 2002, at 6; McCain Willing to Consider Resolution on UNE-P, TELRIC, TRDAILy, Sept. 24, 2002, at 3; Z-Tel Questions Bells' UNE-P Financial Claims, TRDally, Sept. 24, 2002, at 9; Rep. Pomeroy: UNE Rates Should Reflect Actual Costs, TRDAILy, Sept. 25, 2002, at 6; SBC Blames Layoffs on Regulation; Ackerman Warns on UNE$P$, TRDaily, Sept. 26, 2002, at 2; SBC's Rivals Question Firm's Motivation for Layoffs; Some Analysts Say Financial Pressure Is Real, TRDAILY, Sept. 27, 2002, at 7-8; Glenn Bischoff, USTA Calls For the End of UNE-P, TELRIC, at http:// www.telephonyonline.com/ar/telecom_usta_calls_end_2/index.htm (Sept. 13, 2002). See also Press Release, SBC, More Than 100 Members of Congress Call for Changes to "Perverse" Telecommunications Regulations (Sept. 17, 2002) (on file with authors) [hereinafter SBC Press Release] (where, according to SBC President Richard Daley, TELRIC pricing is "below cost" and is an "irrational and unsustainable subsidy that is threatening the future of our nation's telecommunications infrastructure"); Seidenberg Says UNE-P Is "Manageable Issue" For Verizon, Wash. Telecom Newswire, Sept. 9, 2002 (according to Verizon Chief Executive Officer Ivan Seidenberg: "'State commissions don't get it. They don't have a clue because they are trapped' in an old view of regulatory policy."). Such criticisms are particularly puzzling given that the Bells publicly reported to the FCC that States imposed TELRIC pricing as a pre-condition of receiving authority under Section 271 of the Telecommunications Act of 1996 to provide in-region inter-LATA service. See, e.g., Ex parte Letter from Gordon R. Evans, Vice President Federal Affairs, Verizon, to Marlene H. Dortch, Secretary, FCC, Verizon Petition for Emergency Declaratory and Other Relief, WC Dkt. No. 02202, In the Matter of Review of the Section 251 Unbundling Obligations of Incumbent Local Exchange Carriers, CC Dkt. No. 01-338, Implementation of the Local Competition Provisions of the Telecommunications Act of 1996, CC Dkt. No. 96-98, and Deployment of Wireline Services Offering Ad- ment and deployment of switching equipment. This claim, however, does not survive econometric scrutiny." Second, and more recently, the BOCs have begun to criticize the state regulatory commissions by accusing the commissions of incorrectly applying TELRIC in their determinations of wholesale prices. ${ }^{12}$ One claim is that the state commissions disregard "true" costs when they set wholesale prices, and instead choose wholesale prices that ensure sizeable margins for CLEC entrants. ${ }^{13}$ Again, empirical evidence does not support the BOCs' claim in this

vanced Telecommunications Capability, CC Dkt. No. 98-147, at 16 (Aug. 16, 2002) (on file with authors) [hereinafter Letter from Evans to Dortch]. See also financial analyses cited infra Part II, pp 108-112.

11 See T. Randolph Beard, George S. Ford and Thomas M. Koutsky, Mandated Access and the Make-or-Buy Decision: The Case of Local Telecommunications Competition, at http:// www.telepolicy.com/BFKFinal.pdf (unpublished manuscript) (2002). See also, Phoenix Center for Advanced Legal and Economic Public Policy Studies, Phoenix Center Policy Bulletin No. 4: The Truth About Telecommunications Investment, at http://www.phoenix-center.org/PolicyBulletin/PolicyBulletin4Final.pdf (June 24, 2003); PHOENIX CENTER FOR Advanced legal and Economic: Public Policy Studies, Phoenix Center Policy Bulletin No. 5: Competition and Bell Company Investment in Telecommunications Plant: The Effects of UNE-P, at http://www.phoenix-center.org/PolicyBulletin/PolicyBulletin.pdf (Sept. 17, 2003); PHOENIX Center for Advanced Legal and Economic Public: Policy Studies, Phoenix Center Policy Bulletin No. 6: UNE-P Drives Bell Investments: A Synthesis Model, at http:// www.phoenix-center.org/PolicyBulletin/PolicyBulletin6fFnal.pdf (Sept. 17, 2003); Phoenix Center for Advanced legal and Economic Public Policy Studies, Phoenix Center Policy Bulletin No. 7: The Positive Effects of Competition on Employment in the Telecommunications Industry, at http://www.phoenix-center.org/PolicyBulletiri/ PolicyBulletin7fFnal.pdf (Oct. 15, 2003).

12 Qwest Joins Bells' Call for Refining TELRIC Standards, TRDAILY, Sept. 27, 2002, at 4 (reporting that Qwest wrote a letter to FCC Chairman Michael Powell claiming that a "wide gulf separates TELRIC as it was originally conceived from TELRIC as it is now being applied in many States."); $S B C$ Urges FCC to 'Clarify' TELRIC in Pending Arbitration, TRDAlLY, Sept. 11, 2002, at 3 [hereinafter $S B C$ Urges $F C C$ ] ("SBC says some of the key inputs being used in state cost proceedings are 'at odds with market realities and inconsistent with the core assumptions inherent in TELRIC itself.'"); Ex Parte Letter from Robert T. Blau, Vice President-Executive and Federal Regulatory Affairs, BellSouth, to Marlene H. Dortch, Secretary, FCC, In the Matter of Review of the Section 251 Unbundling Obligations of Incumbent Local Exchange Carriers, CC Dkt. No. 01-338 (Aug. 28, 2002) (on file with authors) ("Some state PSCs have abandoned any semblance of cost (including TELRIC) in setting wholesale rates.") [hereinafter Letter from Blav to Dortch].

13 See, e.g., SBC Press Release, supra note 10; see also SBC Urges FCC, supra note 12 (quoting the SBC President William Daily as stating that "in some cases, state regulatory commissions 'make no attempt even to determine the correct input' 
regard. ${ }^{14}$

An alternate, but related claim, is that wholesale prices for UNE-P do not cover the BOCs' actual operational costs for supplying a switched access line. ${ }^{15}$ Financial analysts have fueled the BOCs' claims against UNE-P, suggesting that revenues from UNE-P are insufficient to cover operating costs, but the accuracy of the calculations made by these analysts on both the revenue and cost sides of the issue has been questioned. ${ }^{\text {it }}$

In this paper, we consider the claims of the BOCs, and the related claims of the financial analysts' reports. Specifically, we provide revenue and cost estimates for the BOCs' switched access lines at both the retail and wholesale level. Our approach is more direct than that of the financial analysts who have typically used completely arbitrary means by which to infer costs. Since public data allows for the more direct calculation of wholesale operating costs, the degree of arbitrariness can be reduced substantially. Further, the cost detail provided in the data allows for better estimates of avoided costs, since certain expenses are avoided (e.g., billing, marketing and customer service) while others are passed along to the CLEC serving the customer (e.g., access charges). ${ }^{17}$

The relationship between UNE-P revenues and wholesale costs requires estimates of revenues. UNE-P revenues realized by the BOCs, however, are not easily computed, at least not correctly. To evaluate the reasonableness of the BOCs' claims regarding UNE-P and "actual" costs, we rely on actual, per-line payments to BOCs by a CLEC using UNE-P to provide service in forty-six states. The service offerings of this CLEC are comparable to

for the TELRIC model . . . Instead, they choose inputs that will achieve a predetermined end-result: a TELRIC rate that will give AT\&T the $45 \%$ margin it demands before it will enter local markets' using . . . UNE-P."); accord, Letter from Blau to Dortch, supra note 12 ("Some state PSCs have abandoned any semblance of cost (including TELRIC) in setting wholesale rates, and instead are increasing resale discounts to levels that AT\&T and other CLECs claim they need to operate profitably in residential markets").

14 T. Randolph Beard and George S. Ford, What Determines Wholesale Prices for Network Elements in Telephony? An Econometric Evaluation, at http://www.phoenix-center.org/ pcpp/PCPI6.pdf (Sept. 2002) [hereinafter Beard \& Ford 2002].

15 See, e.g., SBC Press Release, supra note 10; see also Letter from Evans to Dortch, supra note 10.

16 Beard \& Ford 2002, supra note 14; Ex Parte Letter from Robert Curtis, President, and Thomas Koutsky, Vice President, Law and Public Policy, Z-Tel Communications, Inc., to other CLECs and the firm provides wholesale services to numerous, large CLECs. ${ }^{18}$ Thus, we have no reason to believe this choice materially affects the findings of the analysis.

The balance of this paper is outlined as follows. In Section II, we briefly discuss the relationship between TELRIC and current operating costs. Generally, TELRIC does not address the revenues needed to cover current or embedded operational costs or depreciation. TELRIC-derived prices may or may not cover such costs. Thus, the BOCs' claims regarding wholesale prices and profit margins based on embedded costs have no meaningful connection to the correct application of TELRIC. Next, in Section III, we present estimates for the BOCs' per-line revenues for UNE-P. We then describe our computation of wholesale costs in Section IV. Computed gross and net profit margins are presented in Section V. We ignore the implications of long-distance margins on the BOCs' financials. Our approach focuses solely on the BOCs as a wholesale provider of local telecommunications plant. The broader policy issues related to competition across telecommunications markets are left for others to debate. In Section VI, we briefly consider the validation of our findings. Concluding comments are provided in Section VII.

\section{CURRENT COSTS, EMBEDDED COSTS, AND TELRIC}

Recent financial analyses by Commerce Capital Markets, Inc. ("CCM"), ${ }^{19}$ Merrill Lynch \& Co., Inc. ("ML"), ${ }^{20}$ and UBS Warburg ("UBS") ${ }^{21}$ have focused attention on the general charge by BOCs

Michael Powell et al., FCC, Dkt. No. 01-338 (Sept. 23, 2002) (on file with authors) [hereinafter Letter from Curtis and Koutsky to Powell]; Ex Parte Letter from Donna Sorgi, WorldCom, Inc. to Michael Powell et al., FCC, Dkt. No. 01338 (Sept. 16, 2002) (on file with authors) [hereinafter Letter from Sorgi to Powell].

17 Access charges are paid by long distance carriers to local exchange calls when originating or terminating a long distance call.

18 Kris Hundley, Venture with MCI gives Z-Tel a Boost, ST. Petersburg Times, Mar. 22, 2002, at E6; Z-Tel and Sprint Sign Agreement for Wholesale Services, Bus. WIRE, Feb. 4, 2003.

19 Anna-Maria Kovacs et al., Commerce Capital MarKETS EQUiTy RESEARCH, The Siatus of 272 and UNE-Platform in the Regional Bells' Territories, (Aug. 22, 2002).

20 Adam Quinton et al., Merril Linch Global. Securities Research \& Economics Group, The Telecommunicator: Telecom Act Seven Years On-The UNE Shock Wave Belatedly Reverberates Around the RBOCs - And How! (Sept. 23, 2002). 
that UNE-P pricing is "confiscatory" (i.e., a rate set by government that is below costs and therefore constitutes an unlawful takings under the U.S. Constitution). ${ }^{22}$ While economists are unlikely to be fully convinced by such analyses (relying, as they do, on the validity of accounting cost data and other strong assumptions), any finding of consistently negative margins for element sales is a cause for concern, regardless of these caveats. Thus, it is worthwhile to evaluate some recent findings on this point in order to highlight the extent to which official concern is warranted.

The issue of the remunerative quality of UNE-P sales by the BOCs highlights several important points relevant to any financial analysis of firm activity. First, for reasons that need not be repeated here, caution should be attached to all such analyses that utilize accounting (rather than economic) $\operatorname{costs.}^{23}$ In general, accounting costs are not equal to economic costs, and profitability in the economic sense is the appropriate yardstick for, and basis of, firm decisions. Nevertheless, we calculate and present the gross EBITDA ${ }^{24}$ and net profit margins (both accounting measures of profit) in what follows.

Second, aggregation will play an important role in our analysis, as it does in the financial analysts' reports we evaluate here. From a theoretical point of view, however, any claim that element sales are "below costs," somehow defined, must be understood as amounting to a claim that "some set of elements are, in fact, sold on below cost terms." The claim that an element could be sold "below cost" is financially irrelevant if no one actually buys the element, or buys the element in combination with other elements priced above costs. Further, elements sold for prices above

21 John Hodulick et al., UBS WARBurg Global EQUity Research, How Much Pain From UNE-P? Analysis of UNE-P Economics for the Bells, (Aug. 20, 2002).

22 For a primer on basic ratemaking principles, see MARK Naftel \& Lawrence J. Spiwak, The Telecoms Trade War: The United States,. The European Union and The WTO (2001).

23 For a general discussion on the use of accounting data, see STEPHEN MARTin, Advanced Industrial Economics $\$ 17(1993)$.

24 EBITDA is an acronym for Earnings Before Interest, Taxes, Depreciation and Amortization.

25 See Section 251 Order, supra note 5, para. 683 ("Forward-looking cost methodologies, like TELRIC, are intended to consider the costs that a carrier would incur in the future."); "We read section 252(d)(1)(A)(i) to prohibit States from conducting traditional rate-of-return or other rate- costs, but below cost-plus-seller-rents, will "damage" the seller financially, in the same manner that a monopolist forced to yield its position is damaged. Damage of this sort is presumably not a public concern per se. These distinctions are largely unaddressed in the financial reports.

Also, as a matter of economic theory, TELRIC pricing is not designed to reimburse the element seller for "actual" or "embedded" costs. ${ }^{25}$ Such embedded costs reflect the cumulative sum of the economic costs of resources acquired by the BOCs over time, not the economic cost or "value" of the elements that were created with those resources. For example, a $\$ 10$ steak burned to a crisp is not worth $\$ 10$, since one could obtain the result-a lump of carbon-for less than $\$ 10$. Nor is a 100-megahertz computer worth $\$ 1,000$ today, despite the fact it sold for that amount a few years ago. In general, the economic cost of a product is the cost of the resources required by an efficient producer to duplicate all the valued services provided by that product.

The determination of wholesale prices for unbundled elements (particularly UNE-P) by state commissions has itself been the subject of recent research. ${ }^{26}$ Although an earlier paper by T. Randolph Beard and George S. Ford ${ }^{27}$ shows that prices are not determined by either the BOCs' embedded costs or retail prices, the authors provide evidence that many state commissions set wholesale prices at a point about halfway between forward-looking costs (economic cost) and forward-looking cost plus the average retail margin. ${ }^{28}$ This latter value approximates the efficient component pricing rule ("ECPR") price, ignoring the lack of competition that gives rise to the relevant economic rents (i.e., profits, loosely defined) ${ }^{29}$

based proceedings to determine rates for interconnection and access to unbundled network elements" Id. at para. 704; "We reiterate that the prices for the interconnection and network elements critical to the development of a competitive local exchange should be based on the pro-competition, forward-looking, economic costs of those elements, which may be higher or lower than historical embedded costs" Id. at para. 705 .

26 See Beard \& Ford 2002, supra note 14.

27 Id.

28 Id. at 12-19.

29 According to the ECPR, the access fee paid by the rival to the monopolist should be "equal to the monopolist's opportunity costs of providing access, including any forgone revenues from a concomitant reduction in the monopolist's sales of the complementary component." Nicholas Economides \& Lawrence J. White, Access and Interconnection 
Thus, while it is correct that TELRIC does not provide a mechanism for embedded cost recovery, it has been modified in practice to allow price increases that compensate the seller for a portion of retail margins.

Thus, the impact of element sales on the BOCs financial performance is a complex matter. BOCs resistance to such sales is proof that the sales reduce BOCs profits. Competition inevitably erodes excess profits and this is desirable for everyone except for the BOCs (and, potentially, their shareholders) ${ }^{30}$ Financial analysts, such as those who produced the Merrill Lynch analysis, are paid to advise investors, not to promote social welfare or competition. However, the BOCs' campaign against the current UNE-P environment seems to suggest that element sales actually threaten the financial solvency of the BOCs. Such solvency does depend on embedded costs, of course, as debt is a current obligation for the past use of resources.

In this paper, we calculate BOC margins for UNE-P sales that include embedded costs as contained in cost data given to the FCC by the BOCs in order to credibly evaluate the implication of the recent analysts' studies that UNE-P is unprofitable for the BOCs. This analysis allows a credible evaluation of the conclusion implied by recent Wall Street financial analysts' reports that UNE-P is unprofitable for the BOCs, potentially leading to under-investment and financial ruin for these telecommunications giants. We endeavor to measure revenues and costs as accurately as possible given the data sources available to us. In so doing, we hope to shed light on the current debate of this matter, and potentially raise the sophistication of future studies on this topic by the financial community.

Pricing: How Efficient is the Efficient Component Pricing Rule? 40 ANTITRust Bull. 557.79 (1995).

30 See, e.g., C.K. Prahalad \& Gary Hamel, The Core Competence of THE Corporation (1994).

31 The unbundled loop is a pair of copper wires that runs from the consumer's household to the BOCs' central office. Switching directs a call to the intended recipient, and if the recipient is not in the same central office as the customer originating the call, the call must be transported over facilities to another central office.

32 The signaling network establishes a "path" between the originating and terminating phone, and ensures that the receiving phone is operational. A daily usage file is a record of call and call lengths for each individual customer. Many installation and repair services are provided to CLECs by the BOCs, and the CLECs compensate the BOCs for such services by paying "non-recurring charges."

\section{BOCS REVENUES FROM WHOLESALE LOCAL EXCHANGE SERVICES}

UNE-P is a combination of numerous unbundled elements including primarily an unbundled loop, unbundled switching, and unbundled transport. ${ }^{31}$ Related elements include: signaling services necessary to route calls, daily usage files (describing customer calling) needed for billing purposes, and non-recurring charges levied when these elements are ordered, provisioned or repaired. ${ }^{32}$ In some states, UNE-P CLECs also pay the BOCs reciprocal compensation, and many continue to use the BOCs' Operator Services and Directory Assistance ("OS/DA"). OS/DA is purchased by the CLEC as a retail service, not as an unbundled element. ${ }^{33}$ In some states, additional sources of revenue are present, such as the Operational Support Systems ("OSS") charge of $\$ 0.55$ per line/month in New York. ${ }^{34}$

\section{A. Sources for BOCs UNE-P Wholesale Prices}

In an effort to measure $\mathrm{BOC}$ revenues from UNE-P, we evaluate four sources of revenue data: three reports from various financial analysts and confidential data provided to the authors by Z-Tel Communications. Z-Tel Communications ("ZTel") is a CLEC that serves customers, via UNE-P, in forty-six states. ${ }^{35}$ Given Z-Tel's actual experience with UNE-P, and its ability to estimate costs directly from the bills it receives from the BOCs, we consider Z-Tel's numbers to be the best indicator of BOC revenues from UNE-P. ${ }^{36}$ That said, ZTel's experience might not be identical to that of other CLECs using UNE-P (e.g., usage or density zone distributions may vary among CLECs). Given

33 In re Implementation of the Local Competition Provisions of the Telecommunications Act of 1996, Third Report and Order and Fourth Further Notice of Proposed Rulemaking, 16 F.C.C.R. 1724, 3891, para. 441-442 (rel. Nov. 5, 1999).

34 This charge is intended to cover the expenses incurred by Verizon to allow its computer systems to handle wholesale operations. See Verizon Telephone Operating Companies Effective Tariffs, Network Elements, pursuant to N.Y. Pub. Serv. Comm'n Tariff No. $10 \$ 5.9 .3$ (on file with authors).

35 Letter from Curtis and Koutsky to Powell, supra note 16.

36 Z-Tel has adjusted its costs to reflect recent changes in wholesale prices in a number of states. In many cases, Z-Tel does not yet pay these rates to the BOCs due to lags in the incorporation of new rates into their interconnection agreements. 
no indication that Z-Tel's experience is atypical for a UNE-P CLEC, we consider Z-Tel's experience to be representative. ${ }^{37}$

\section{B. Difficulties in Estimating Wholesale Prices for UNE-P}

Computing the BOCs' revenues from UNE-P is a difficult task. Financial analysts typically compute UNE-P revenues as if rates simply can be multiplied by usage and added to flat charges, but it is not that easy. ${ }^{38}$ For example, switching typically consists of a flat-rated port charge, features charges and per-minute charges. ${ }^{39}$ In some states (e.g., Illinois, Indiana and Wisconsin), the usage costs are included in the port charge, and in others the feature charges are included in the port charge. In several states, usage and features charges are separate from the port charge. Additionally, CLECs vary in their demands for features, and their customers are likely to vary in their usage patterns. ${ }^{40}$ With respect to usage, the application of specific usage charges varies by $\mathrm{BOC}$, and frequently varies within a single BOC region. For example, in some states, an intraswitch call incurs two minutes of switching per minute of conversation (e.g., West Virginia), while in others an intra-switch call incurs only a single minute charge per minute of use. In some states reciprocal compensation is paid by the CLEC (e.g., the former Ameritech states), whereas other states have adopted a bill-and-keep arrangement. In some states served by Verizon Communications, Inc. ("Verizon"), terminating switching and

37 Data provided by SBC to the FCC indicates that Z-Tel's experience in the $S B C$ region is typical, and that the distribution across density zones of UNE-P entry closely parallels the distribution of access lines across such zones. See Ex Parte Letter from Jay Bennett, Executive Director - Federal Regulatory, SBC Communications, Inc., to Marlene $\mathrm{H}$. Dortch, Secretary, FCC, In the Matter of Review of the Section 251 Unbundling Obligations of Incumbent Local Exchange Carriers, CC Dkt. No. 01-338 (Oct. 11, 2002) (on file with authors) [hereinafter Letter from Bennett to Dortch].

38 Charges for unbundled switching typically consist of a flat monthly fee (a port charge) and a fee-per-minute of usage (usage-based charges). There may be many applicable usage charges depending on the time the call is made, how far the call travels and what equipment is used to send the call to its destination. Thus, information is needed on the total number of minutes, when calls were made and where calls originated and terminated.

39 Charges for switch features (e.g., caller ID, call waiting, etc.) are levied either on a per-feature or all-features basis.

40 Customers with high usage (and thus spending) stand reciprocal compensation are treated as offsets in a type of pseudo bill-and-keep arrangement (e.g., New York). In states where switching charges are usage sensitive, the usage of the customers can matter substantially (depending on the per-minute switching rate). Computing transport cost is particularly difficult, and the application of charges varies substantially across states. Transport costs, however, are generally a small portion of total UNE-P revenues (typically less than five percent for Z-Tel). ${ }^{41}$

\section{Revenue from Non-Recurring Activities}

Non-recurring charges ("NRCs") are another source of revenue for the BOCs from UNE-P, but this revenue is frequently ignored in the analysts' reports. ${ }^{42}$ In principle, non-recurring charges compensate the ILEC for expenses associated with taking orders for, and provisioning a line to, a CLEC. For UNE-P, there are typically three categories of non-recurring costs. For ordering and provisioning a customer, there is either a "migration" NRC or a "new install" NRC. The "migration" NRC is paid when the customer already has service with the ILEC, whereas the "new install" NRC is paid when the customer does not have existing service ${ }^{43}$ Because the Automated Reporting Management Information System ("ARMIS")44 data includes all labor and provisioning expenses regardless of whether such costs relate to services provided to the ILEC itself or its CLEC customercompetitors, the costs related to ordering and provisioning services to CLECs are included in

the most to gain from a price decrease, so it is likely that CLEC customers are, on average, more intense users of telecommunications services.

41 Computed by dividing transport costs by total costs using data provided to the authors by Z-Tel Communications.

$42 \mathrm{CCM}$ includes some revenues for NRCs in its analysis, but the charges appear to be grossly understated and are amortized over three years (which is a relatively long customer life and an inappropriate method by which to assess BOCs revenue from NRCs). For purposes of comparison, the NRC revenues are excluded from the summary figures in Table 2.

43 There are also NRCs for "change orders," such as when a customer wants a new phone number or some other change occurs to their account. We do not include revenues from such activities, thus making our NRC revenues understated.

44 ARMIS is the detailed cost information BOCs provide to the FCC. See Federal Communications Commission, Electronic ARMiS Filing. SyStem (EAFS) Retrieval Module, at http://gullfoss2.fcc.gov/eafs/MainMenu.cfm (last modified Apr. 1, 2003). 
the ARMIS expense data. Because the expenses related to such activities are included in the analysis on the expense side, it is therefore necessary to include revenues from NRCs in the analysis on the revenue side.

Publicly available information from CLECs suggests that about one-third of customers are new installs, and we assume that this is typical for the purposes of our calculations. ${ }^{45}$ FCC data indicates that there were 5.6 million UNE-P lines at yearend 2001.46 These access lines are allocated across states based on the relative shares from the Form 477 data. ${ }^{47}$ This data indicates that UNE-P lines increase, on average, by about $3.6 \%$ per month (from June to December 2001). ${ }^{48}$ Public information suggests a monthly churn rate for UNE-P customers of about $6.67 \%$, which can be added to the customer base growth rate of $3.6 \%$ for a total migration/new-install rate of about $10.25 \% .^{49}$

Table 1. Average Non-Recurring Charge Revenue for UNE-P (Excluding Change Order NRCs)

\begin{tabular}{lrrcc}
\hline \multicolumn{1}{c}{ BOC } & Share & $\begin{array}{c}\text { UNE-P } \\
\text { Lines }^{a}\end{array}$ & Avg. NRC & Per- Line \\
\hline Verizon & $39 \%$ & $2.19 \mathrm{M}$ & 13.12 & 1.34 \\
BellSouth & $11 \%$ & $0.62 \mathrm{M}$ & 12.27 & 1.26 \\
SBC & $42 \%$ & $2.39 \mathrm{M}$ & 25.67 & 2.63 \\
Qwest & $8 \%$ & $0.46 \mathrm{M}$ & 20.37 & 2.09 \\
\hline BOC-Wide & $100 \%$ & $5.66 \mathrm{M}$ & 18.73 & 1.92 \\
\hline
\end{tabular}

"FCC Form 477 Data (December 2001).

${ }^{\text {b }}$ Z-Tel Communications.

Access line weighted NRCs by BOC (one-third new install, two-thirds migration) are presented in Table 1 (change order NRCs are ignored). To compute the per-line NRC, the average BOC NRC is multiplied by the $10.25 \%$ growth/churn rate.

45 George S. Ford, Reply Testimony on Behalf of Z-Tel Communications, Inc. before the Indiana Utility Regulatory Commission, (Nov. 11, 2001) (transcript on file with authors).

46 U.S. Telephone Ass'N, UNE Fact Report (2002) at Table 3 [hereinafter UNE FACT REPORT 2002].

47 Form 477 data is that data collected by the FCC from CLECs and BOCs regarding the number of access lines served and/or sold. The Form 477 data does not include data for all States due to confidentiality concerns, so we rely on the total number of UNE-P lines from the UNE FACT REPORT 2002, supra note 46, using the State specific information from the Form 477 data to allocate across BOCs. For details, see Federal Communication Commission, Frequently Asked Questions (FAQ), About FCC Form 477 (Local CoMpetrTION AND BROADBAND REPORTING), at http://ftp.fcc.gov/ broadband/broadband_data_faq.html (last modified Feb. 1, 2002).

48 Computed as the percentage increase in UNE-P access
As shown in Table 1, the average monthly revenue per UNE-P line from NRCs is $\$ 1.92$ and ranges from $\$ 1.26$ in the BellSouth Region to $\$ 2.63$ in the $\mathrm{SBC}$ region.

\section{Wholesale Prices for UNE-P}

Keeping in mind the difficulties of accurately calculating UNE-P revenues, the estimates of CCM, ML, UBS and Z-Tel are summarized in Table 2. Estimates are provided at the BOC level only, to protect (to some degree) the confidentiality of the Z-Tel data. Table 2 illustrates the sizeable understatement of UNE-P revenues by the financial analysts. Z-Tel pays the BOCs about $43 \%$ more than the UBS estimates, $30 \%$ more than the ML estimates and $11 \%$ more than the CCM estimates (without NRCs). These differences may emerge from differences in the distribution of loop rates across density zones, different usage patterns, different assumptions regarding the number of features purchased, the exclusion of costs related to some elements, and various other reasons. ${ }^{50}$ CLECs have indicated that usage is one primary detriment of the differences between actual costs and the costs estimated by the analysts. ${ }^{51}$

Also observe (in Table 2) that, on average, the inclusion of the NRC revenue increases $B O C$ revenues from UNE-P by about $9 \%$. Overall, actual CLEC experience suggests that the revenues received by BOCs are considerably higher than the financial analysts' estimates indicate. This general understatement of revenues by financial analysts is important since when evaluating EBITDA margins (or any margin for that matter), small

lines across states between June and December 2001 (divided by six to produce a monthly growth rate).

49 The estimated churn rate of about $6.7 \%$ is based on Comments of Kimberly Scardino, Senior Counsel, WorldCom, Inc., In re Review of the Section 251 Unbundling Obligations of Incumbent Local Exchange Carriers, CC Dkt. No. 01338 (Nov. 15, 2002) (on file with authors).

50 The loop rate is the charge for the copper wire that runs from the consumer's household or business to the BOCs' central offices. It is a flat, monthly recurring price and has no usage-sensitive price component. Differences in loop rates explain about $\$ 0.36$ of the difference between Z-Tel and CCM, on average. UBS assumes $80 \%$ of access lines are in the Urban (Zone 1) density zone. Recent SBC data suggests that only $25 \%$ of UNE-P lines are in the Urban zone. See Letter from Bennett to Dortch, supra, note 37.

51 See, e.g., Letter from Curtis and Koutsky to Powell, supra note 16; Letter from Sorgi to Powell, supra note 16. 
changes in revenues or costs are reflected directly in the margin.

Table 2. BOC Specific UNE-P Revenues Per Line (Dollars per line/month)

\begin{tabular}{lcccc}
\hline & UBS & ML & CCM & ZTEL \\
\hline $\begin{array}{l}\text { Without NRC Revenue } \\
\text { Verizon }\end{array}$ & 15.08 & 17.29 & 20.20 & $\mathbf{2 3 . 0 8}$ \\
BellSouth & 18.79 & 19.97 & 24.38 & $\mathbf{3 1 . 5 4}$ \\
SBC & 13.98 & 15.02 & 17.31 & $\mathbf{1 7 . 9 4}$ \\
Qwest & 18.53 & 21.05 & 23.98 & $\mathbf{2 2 . 5 4}$ \\
BOC-Wide & 15.75 & 17.37 & 20.30 & $\mathbf{2 2 . 5 1}$ \\
\hline With NRC Revenue & & & & \\
Verizon & 16.43 & 18.63 & 21.54 & $\mathbf{2 4 . 4 3}$ \\
BellSouth & 20.05 & 21.23 & 25.64 & $\mathbf{3 2 . 8 0}$ \\
SBC & 16.61 & 17.65 & 19.94 & $\mathbf{2 0 . 5 7}$ \\
Qwest & 20.61 & 23.14 & 26.07 & $\mathbf{2 4 . 6 3}$ \\
BOC-Wide & 17.67 & 19.29 & 22.22 & $\mathbf{2 4 . 4 3}$ \\
\hline
\end{tabular}

Weighted averages based on switched access lines from ARMIS data (2001), and therefore may be slightly different from those reported in the respective analysts reports.

There are two methods by which the quality of the analysts' estimates can be evaluated, and these two methods are best applied jointly. First, we can evaluate the average revenue (at the BOC level) to determine how close the estimates are to actual experience. Table 2 provides such a comparison and indicates the financial analysts' estimates of revenue are far below the actual experience of a UNE-P CLEC. Second, we consider the fact that the BOCs average revenues are averages of statelevel UNE-P revenues per line. Because a good estimate of a BOC's average revenue from a UNE$P$ line could arise from state-level revenue estimates that are entirely unrelated to what CLECs actually pay, we also examine the correlation between the state-level revenue estimates and actual experience. ${ }^{52} \mathrm{~A}$ high positive correlation would suggest that the Wall Street analysts' estimates may accurately reflect a BOC's average UNE-P revenue per line. The correlation matrix is provided in Table 3. Although the correlation coefficients between the analysts' estimates and Z-Tel's actual experience are positive, the correlations are not very large (i.e., not close to 1.00 which indicates perfect correlation). Thus, the analysts' estimates

52 For example, the number pairs $(10,20)$ and $(25,5)$ both average to $\$ 15$, but the average is based on very different underlying values.

53 The EBITDA margin equals revenue minus all expenses except for interest, taxes, depreciation and amortization. Thus, increases in revenue, holding expenses constant, are poor reflections of actual revenues from UNE$P$ under both evaluation methods.

Considering both the level and correlation of the analysts' estimates to actual experience, the "best" analyst estimate of UNE-P revenues is provided by CCM, which underestimates Z-Tel's actual experience by about $11 \%$ and has a correlation coefficient of 0.68 (excluding NRCs). Most of this difference is observed in the BellSouth region. Even though $10 \%$ may seem to be a relatively small difference, the additional $\$ 2.21$ in revenue it represents is important when computing EBITDA margins. ${ }^{53}$ Further, on a state-specific basis, there may be very large differences that are masked in the average (but revealed to some degree by the correlation coefficient). For example, in one state, CCM underestimates Z-Tel's wholesale prices by $56 \% .{ }^{54}$ In seven out of forty-six states $(15 \%)$, CCM understates BOC wholesale prices by $25 \%$ or more. ${ }^{55}$ In some cases, CCM overstates $\mathrm{BOC}$ wholesale prices (but none by as much as $25 \%$ ). Overall, CCM understates BOC revenues for $65 \%$ of states with an average understatement of $16 \%$, whereas CCM overstates revenues for $35 \%$ of states with an average overstatement of $8 \%$.

Table 3. UNE-P Revenues Correlation Matrix

\begin{tabular}{lcccc}
\hline & CCM & ML & UBS & ZTEL \\
\hline CCM & 1.00 & 0.87 & 0.66 & 0.68 \\
ML & 0.87 & 1.00 & 0.77 & 0.64 \\
UBS & 0.66 & 0.77 & 1.00 & 0.57 \\
ZTEL & 0.68 & 0.64 & 0.57 & 1.00 \\
\hline
\end{tabular}

Regardless of the source of the revenue estimates, SBC clearly has the lowest per-line revenue from UNE-P of the four BOCs (see Table 2), driven primarily by the low UNE-P rates in the former Ameritech region. BellSouth has the highest UNE-P revenues per line according to CCM and Z-Tel, and Z-Tel data indicates that BellSouth's rates embody high charges for switch features and the daily usage file, charges that do not appear to be properly accounted for by UBS, ML and CCM. For example, in Alabama, the switch features (as a

increase EBITDA.

54 Computed as the percentage difference between the average cost-per-line as reported by Z-Tel and CCM.

55 Based on a state-by-state comparison of the average UNE-P costs reported by Z-Tel and CCM. 
bundle) have a wholesale price of $\$ 5.55$ and the switch port is $\$ 2.07$ (for a port/features total of $\$ 7.62$, not including usage). ${ }^{56}$ Yet, the CCM data lists switching costs in Alabama (including usage and transport) of only $\$ 5.46$, UBS lists $\$ 4.67$, and ML lists $\$ 3.77$. Clearly, the financial analysts have not estimated UNE-P revenues correctly (at least for some states). Understating revenues, even by a small amount, is a non-trivial matter when computing EBITDA margins on a BOC or state-level basis.

\section{RETAIL AND WHOLESALE COSTS PER ACCESS LINE}

Through ARMIS, the BOCs report detailed cost information to the FCC. This data is highly disaggregated, unlike the financial forms submitted to the Securities and Exchange Commission. Using this data, we compute the average retail and wholesale cost per line for each BOC. The ARMIS does not, however, directly allocate costs between retail and wholesale functions. To compute wholesale costs, we exclude, as best we can, costs associated with the provision of retail services by the BOC. Once the wholesale costs are computed, we can then compare these wholesale costs to revenues received from CLECs using UNE-P.

\section{A. Wholesale Operating Expenses}

BOC expenses related primarily to the provision of switched access line services are summarized in ARMIS Form 43-01 (Year 2001) ("Form 43-01"). ${ }^{57}$ The major categories of operating costs from Form 43-01 are summarized in Table 4. We include only costs that are allocated in Form 43-01 to "Common Line" (i.e., loops), "Traffic Sensitive Switching," and "Traffic Sensitive Transport."58 These expenses are summarized for the interstate portion alone in ARMIS, so we convert these to total expenses by dividing the reported expenses

56 See Agreement between BellSouth Telecommunications Inc. and Z-Tel Telecommunications Inc., June 2000, at 168,171 (on file with authors)

57 Other Forms provide similar information, often at a higher or lower level of aggregation.

58 Basic telephone service, such as UNE-P, includes loops, switching and transport network elements.

59 These calculations follow exactly those made by a BOCs expert witness. See Dr. Debra J. Aron, Testimony on by the appropriate separations factor: Common Line expenses are divided by 0.25 , switching expenses are divided by the ratio of interstate to total ("Subject to Separations") dial equipment minutes ("DEMS"), and transport expenses are divided by twice the aforementioned DEMS ratio. ${ }^{59}$ The operating costs listed in Table 4 are further disaggregated in other ARMIS forms, including ARMIS Forms 43-03 and 43-04. Our analysis is limited to the summary categories only, with the exception of "Plant Non-Specific" expenses, which contains some cost elements that should be allocated between wholesale and retail segments.

Table 4. Expense Categories ARMIS Form 43-01

\begin{tabular}{cl}
\hline Row_\# & \multicolumn{1}{c}{ Row_Title } \\
\hline 1120 & Plant Specific \\
1130 & Plant Non-Specific \\
1140 & Customer Operations Marketing \\
1150 & Customer Operations Services \\
1160 & Corporate Operations \\
1170 & Access \\
1180 & Depreciation/Amortization \\
1185 & FCC Expense Adjustment \\
1190 & Total Operating Expenses \\
\hline
\end{tabular}

While Form 43-01 provides expense data at the state level, it appears that the allocation of expenses across states does not allow for reasonable state-specific estimates of expenses to be computed. For example, negative expenses are listed in some cases. ${ }^{60}$ Also, expenses of nearly all types appear to be over-allocated to New York, Georgia, Texas and Colorado-states where the BOC's corporate headquarters are located. ${ }^{61}$ ARMIS includes a substantial degree of allocation across states, and we wish to avoid to the greatest extent possible any arbitrariness that may accompany such allocations. Thus, we compute expenses and profit margins at the BOC level.

All "Plant Specific" expenses are included in our measure of wholesale costs. Since some of these costs may be related to data services, this assumption, if anything, overstates actual wholesale

Behalf of Southwestern Bell Telephone L.P. d/b/a Southwestern Bell, Before Public Utility Commission of Texas, Texas Dkt. No. 25834 (Nov. 4, 2002) (transcript on file with authors). The DEMS factors are computed from ARMIS Form 43-04, Row 1216.

60 For example, Corporate Operations Expenses (ARMIS Form 43-04, Row 1160) in Missouri are negative.

61 Headquarter states are New York (Verizon), Georgia (BellSouth), Texas (SBC) and Colorado (Qwest). 
expenses per line. From "Plant Non-Specific" expenses, we exclude costs related to Terminal Equipment, and half of those costs related to artwork, furniture, general computers and similar items are assigned to the retail segment. ${ }^{62}$ "Corporate Operations" expenses are assigned using an expense allocation factor, where the factor is equal to the adjusted plant expenses divided by total expenses (excluding "Corporate Operations" and "Depreciation"). ${ }^{63}$ "Access" expenses are a retail expense. ${ }^{64}$ Depreciation is a capital expense and is discussed in the next section.

While the wholesale segment of the BOC does not have retail customers, it will have wholesale customers. For each BOC, we assume that the wholesale customer service and billing operations is equal in size to the BOC's current expenses related to the billing and collection of access charges from interexchange carriers (a wholesale function). ARMIS Form 43-01 provides this expense data. ${ }^{65}$

\section{B. Wholesale Capital Costs}

\section{Positive EBITDA margins do not guarantee ac-}

62 These expenses are detailed in ARMIS Form 43-03, Rows $6121,6122,6123$, and 6124 . Terminal equipment is not related to the provision of UNE-P services.

63 The average allocation factor is $69 \%$, so much of Corporate Operations is assigned to the wholesale segment.

64 Access expenses are reported as zero in ARMIS Form 43-01 for "Common Line" and "Traffic Sensitive" cost categories.

65 We include total expenses in the "Billing and Collection" category from ARMIS Form 43-01.

66 The return to capital is never included as an expense category in financial reporting, and depreciation and amortization are left out of EBITDA because neither is a cash expense.

67 Switched access lines are increased by $5 \%$ to account for unbundled lines that are excluded from ARMIS data. See Dr. Debra J. Aron, Supplemental Response to RFI No. 1-1a, Texas Dkt No. 25834, request No. 1, at 8 (Nov. 4, 2002) (on file with authors). SBC reported that its net plant for analog access is $\$ 499$ per line in the former Ameritech region. See Ex Parte Letter from Brian J. Benison, Associate Director-Federal Regulatory, SBC Telecommunications, Inc., to Marlene H. Dortch, Secretary, FCC, In the matter of Review of the Section 251 Unbundling Obligations of Incumbent Local Exchange Carriers, CC Dkt. No. 01-338 (Oct. 30, 2002) at 3 (on file with authors). Our computations compute a net plant for this region of $\$ 550$. Thus, we adjust the net plant calculations downward to $91 \%$ of the computed value from ARMIS to produce an estimate for analog dialtone lines.

68 The capital charge factor is $[(1-\mathrm{A}(N, r)(t / N))] /[(1-$ $t) \mathrm{A}(N, r)]$, where $t$ is the tax rate, $N$ is the depreciation life, $\mathrm{A}(N, r)$ is the present value of a $\$ 1$ annuity for $N$ years computed at the after-tax rate of return equal to $r$ percent. De- counting profitability, as costs associated with capital investment (depreciation and a return to capital) are left out of the calculations. ${ }^{66}$ Profitability can be assessed, however, by including levelized capital expenses per access line in the analysis.

ARMIS Form 43-01 provides average net plant data (Year 2001) for the "Common Line" and "Traffic Sensitive" cost categories, which are converted to a per-line net plant by application of the allocation factors to produce total net investment and then dividing by switched access lines. ${ }^{67} \mathrm{Net}$ plant is converted into a monthly capital payment by multiplying net plant by the annual capital charge factor and dividing by twelve. Application of the annual capital charge factor to investment produces a monthly payment that includes the depreciation and return on the investment, including the tax effects. ${ }^{68}$

\section{Summary of Cost Estimates}

Table 5 summarizes the BOC-specific and BOCwide average retail and wholesale operating and total expenses. ${ }^{69}$ Retail expenses per line are estimated to be $\$ 20.90$ per line, which is comparable

preciation life is computed as the inverse of the percentage of net plant depreciated each year (i.e., the ratio of the change in accumulated depreciation and net plant). According to ARMIS Form 43-02, accumulated depreciation is about $10 \%$ of net plant per year on average, implying a 10 -year depreciation life. The depreciation life varies by BOCs (Verizon: nine years; BellSouth: ten years; SBC: eleven years; Qwest: twelve years). The tax rate is computed from the BOCs' Form 10-K. The cost of capital is based on the following assumptions: (a) the cost of short-term debt is $1.31 \%$, which is the yield on 3-Month Non-Financial Commercial $\mathrm{Pa}$ per in December 2002; (b) the average of A and AA rated corporate bonds in December 2002; (c) an average of the cost of equity of $7.52 \%$ computed using the Discounted Cash Flow ("DCF") method (which, in is most basic form, sets the cost of equity equal to the dividend yield plus the expected growth rate in earnings or dividends) using the average of the BOCs dividend yields and consensus growth estimates as of December 2002 (data can be researched at REUTERS INVESTER at http://www.multexinvestor.com); and (d) a capital structure of $40 \%$ debt and $60 \%$ equity, with short-term debt making up $20 \%$ of debt. As of December 2002, the inputs for the DCF method were (Dividend Yield, Long-term Growth): Verizon $(3.89 \%, 4.08 \%)$, BellSouth $(2.95 \%, 4.06 \%)$ and SBC $(3.74 \%, 3.85 \%)$. Given the publicly disclosed problems with Qwest's financial statements, we exclude Qwest from the computation. The capital charge factor is computed for each BOCs, and is based on an average cost of capital of $6.39 \%$.

69 Retail costs are computed using ARMIS Form 43-03. Based on the allocations in ARMIS Form 43-01, we assume $75 \%$ of expenses in this form are allocated to switched access lines (25\% to special access lines). Depreciation is excluded as it is a capital cost. 
to ML's estimate of $\$ 19.95$ and UBS's estimate of $\$ 19.10 .{ }^{70}$ Wholesale operating expenses per line range between $\$ 9.49$ to $\$ 10.91$ across BOCs, and average $\$ 10.15$. In every case, wholesale operating costs are considerably less than the estimates of either ML (\$17.46) or UBS $(\$ 17.02) .{ }^{71}$ Table 5 suggests that wholesale costs equal about $50 \%$ of retail costs, not the $12.5 \%$ assumed by ML or the $11 \%$ assumed by UBS. ${ }^{72}$ Moreover, UBS's assumed avoided cost of $11 \%$ is barely sufficient to account for unquestionably avoidable expenses such as sales, marketing, and customer service. Clearly, the financial analysts have substantially overstated wholesale costs.

Capital costs average $\$ 7.32$ per line/month, ranging from $\$ 6.42$ to $\$ 9.35$. Total wholesale expenses per line-including capital costs-are $\$ 17.55$ on average. Total wholesale expenses are about $38 \%$ less than total retail expenses per line/ month, on average. BellSouth has the highest and SBC has the lowest total wholesale expense. This relation holds for UNE-P revenues as well, though BellSouth's revenue advantage substantially exceeds the cost differential.

\begin{tabular}{lcrcccc}
\hline \multicolumn{7}{c}{ Table 5. BOC Retail and Wholesale Costs } \\
\hline & $\begin{array}{c}\text { Retail } \\
\text { Costs }\end{array}$ & $\begin{array}{c}\text { Operating } \\
\text { Expense }\end{array}$ & $\begin{array}{c}\text { Net } \\
\text { Investment }\end{array}$ & $\begin{array}{c}\text { Capital } \\
\text { Expense }\end{array}$ & $\begin{array}{c}\text { Total } \\
\text { Retail } \\
\text { Expense }\end{array}$ & $\begin{array}{c}\text { Total } \\
\text { Wholesale } \\
\text { Expense }\end{array}$ \\
\hline Verizon & 20.69 & 10.80 & 517.82 & 7.15 & 27.84 & 17.95 \\
BellSouth & 21.41 & 10.91 & 726.28 & 9.35 & 30.76 & 20.27 \\
SBC & 21.44 & 9.49 & 529.82 & 6.42 & 27.86 & 15.91 \\
Qwest & 19.03 & 9.55 & 671.79 & 7.72 & 26.75 & 17.27 \\
\hline BOC-Wide & 20.90 & 10.15 & 578.45 & 7.32 & 28.22 & 17.47 \\
\hline
\end{tabular}

Considering the systematic understatement of UNE-P revenues and the overstatement of wholesale costs, it is no surprise that the analysts find the UNE-P wholesale business unprofitable for the BOCs. We have made clear here, however, that the analysts' findings are (at least partially)

7o The similarities are not surprising, given that ML uses BOCs aggregate data from the FCC STatistics of CoMmuniCATIONS Common Carriers (2001), which is based on the ARMIS data. For State-level estimates of costs, ML simply adjusts the BOCs-wide average operational costs in direct proportion to differences in revenues across States (i.e., the retail EBITDA margin is equal in every State). UBS computes average retail costs by assuming a constant EBITDA margin (across States within a BOCs region) on retail revenues, ignoring actual cost data.

71 CCM also provides cost estimates, but these estimates exceed retail revenues (with costs averaging about $\$ 45$ per line). Consequently, we do not believe these estimates are credible or worthy of a detailed evaluation. CCM also includes ARMIS depreciation expenses, which are notoriously the result of poorly estimated revenues and expenses, and consequently provide little information of value either in an investment or policy context.

Table 6. Marginal Effects of Assumptions on Wholesale Costs

(Dollar change for a one percentage-point change in assumption)

\begin{tabular}{lccc}
\hline & $\begin{array}{c}\text { Corporate } \\
\text { Operations }\end{array}$ & $\begin{array}{c}\text { Cost of } \\
\text { Capital }\end{array}$ & $\begin{array}{c}\text { Avoided Non-Plant } \\
\text { Specific }\end{array}$ \\
\hline Verizon & 0.036 & 0.38 & .020 \\
BellSouth & 0.026 & 0.54 & .017 \\
SBC & 0.015 & 0.39 & .029 \\
Qwest & 0.027 & 0.50 & .022 \\
BOC-Wide & 0.025 & 0.43 & .023 \\
\hline
\end{tabular}

Many alternative assumption sets could be used to compute estimates of wholesale costs. In our computations, we attempted to limit the number of assumptions as much as possible. To assess the effect of alternative assumptions, the "marginal effects" of each input are summarized in Table 6. For example, the last cell in column two of Table 6 indicates that for every one percentage-point change in "Corporate Operations" expenses allocated to wholesale lines, the monthly per-line wholesale operating costs increase by $\$ 0.025$ at the BOC-wide level. ${ }^{73}$ The last cell of column five indicates that a one percentage-point increase in the allocation of furniture, artwork, general computers and so forth to wholesale service, increases wholesale costs by about $\$ 0.023$ (at the BOC-wide level). ${ }^{74}$ The other cells in the table are interpreted in the same manner.

\section{REVENUES, EXPENSES, AND THE EBITDA MARGIN}

To evaluate the accounting profitability (not eco-

incorrect and substantially different from depreciation reported in financial statements. See ANNA-Maria Kovacs eT al., Commerce Capital Markets Status and Implications of UNE-Platform in Regional Bell Markets (2001).

72 Note that the avoided cost discounts computed using the ARMIS data are not directly comparable to the Total Service Resale discounts; those discounts are applied to revenues, not costs. Additionally, the ILECs continue to incur costs for resellers that are avoided for UNE-P (e.g., Access Expenses).

73 The average allocation is $69 \%$ of Corporation Operations to wholesale services.

74 The average allocation is $50 \%$ of such expenses to wholesale services. 
nomic profitability) of the wholesale UNE-P relative to its retail equivalent, the gross (EBITDA) and net profit margins for UNE-P wholesale services sold by the BOCs are computed. ${ }^{75}$ These margins equal the difference between UNE-P revenues from Table 2 and the wholesale costs from Table 5. A minimum requirement for accounting profitability, on average, is that the revenues from a service cover the operating expenses incurred in providing it, excluding any costs associated with capital investment. A positive gross margin indicates that this minimal standard of accounting profitability is met. The net margin is an indicator of actual profitability. The margins, presented for each BOC, are summarized in Table 7.

\begin{tabular}{lccccccc}
\hline \multicolumn{6}{c}{ Table 7. EBITDA Margins for BOC Wholesale Services (UNE-P) } \\
\hline & $\begin{array}{c}\text { UNE-P } \\
\text { Revenues }\end{array}$ & $\begin{array}{c}\text { Wholesale } \\
\text { Costs }\end{array}$ & $\begin{array}{c}\text { Gross } \\
\text { EBITDA) } \\
\text { Margin }\end{array}$ & $\begin{array}{c}\text { Total } \\
\text { Wholesale } \\
\text { Expense }\end{array}$ & $\begin{array}{c}\text { Net } \\
\text { Margin }\end{array}$ & $\begin{array}{c}\text { Implied } \\
\text { Return }\end{array}$ \\
(Pre Tax)
\end{tabular}

On average, the average gross margin for the BOCs is $\$ 14.28$, or $58 \%$ of wholesale revenues. ${ }^{76}$ The margins vary substantially, with the largest margins found in the BellSouth region (\$21.89) and the smallest in the $\mathrm{SBC}$ region $(\$ 11.08)$. Considering its relative low gross margins on wholesale services, SBC's leadership role in attacking UNE-P and TELRIC is unsurprising.

Including capital expenses in the computation of wholesale margins, which results in an estimate of excess return, does not alter the conclusionswholesale margins remain positive. On average, the wholesale net margin is $\$ 6.96$, or $28 \%$ of revenues. Again, SBC has the lowest margin (\$4.66) and BellSouth the highest (\$12.53). Implied returns to capital are summarized in the final column of Table 7. These implied returns are computed by increases in the assumed cost of capital until net income is zero. On average, the return to capital for wholesale access lines is $20 \%$. Thus,

75 Generally, accounting costs do not equal economic costs, particularly for capital expense components of financial data. See Jeremy Edwards et al., The Economic Analysis of Accounting Profitability (1987).

76 These margins are generally consistent with those reported in Beard \& Ford 2002, supra note 14, which reports an average EBITDA margin of $40 \%$. The differences in the margins are attributed mostly to the use of the CCM revenue from the perspective of a wholesale provider of telecommunications plant, UNE-P is profitable.

\section{VALIDATION}

Our analysis of wholesale costs indicates that, on average, the wholesale cost for a switched access line (i.e., the type of line relevant to UNE-P) is $\$ 10$ and depreciation/amortization expenses are about $\$ 7$ on a per-line basis. These estimates suggest that current/embedded total wholesale expenses per line are about $\$ 17$.

Ideally, there would be some way to validate our estimates with real-world experience. Recent statements by SBC's Chief Financial Officer, Randall Stephenson, provide such validation. Specifically, at the Bank of America Securities 32nd Annual Investment Conference in September 2002, Mr. Stephenson stated: "[in] Texas, it's about a $\$ 20$ [to] \$21 UNE-P. [In] Texas, you have a pretty rational model. [A] $\mathbf{t} \$ 20$ [to] $\$ 21$, you have good, vibrant competition and it's not at such a level where we cannot earn money or are disincented to invest."77

Our estimates suggest that with $\$ 20$ to $\$ 21$ in UNE-P revenues per line, the BOCs are fully compensated for their wholesale operating costs and depreciation/amortization expenses. So, our estimates are consistent with the statement that "at $\$ 20$ to $\$ 21$ " the BOCs can "earn money" and are not "disincented to invest." In fact, SBC earns about a $19 \%$ return for UNE-P revenue of about $\$ 20.50$ (see Table 7). On average, BOCs would earn a return of $15 \%$ at UNE-P revenues of $\$ 20.50$ per line/month.

Mr. Stephenson also indicated that a UNE-P price of $\$ 14$ is "below cost." 78 Thus, it is reasonable to conclude that $\mathrm{SBC}$ views its wholesale costs per UNE-P line as somewhere between $\$ 14$ and $\$ 20$. Our estimated average wholesale cost of about $\$ 15.97$ for SBC and $\$ 17.42$ for all BOCs is again consistent with the claims of one BOC's Chief Financial Officer.

data in the earlier paper and to differences in the computation of wholesale costs per line.

77 Randall Stephenson, Remarks at the Bank of America Securities 32nd Annual Investment Conference (Sept. 23-26, 2002) (transcript at http://www.telepolicy.com/randall.pdf).

78 Id. (stating that "it is well below cost on anybody's cost modeling assumptions" and "you cannot get to a $\$ 14$ UNE price"). 
We reiterate, however, that according to FCC policy, wholesale prices should not be set such that the BOCs "earn money" at the current level of expenses. Wholesale prices are based on TELRIC, and TELRIC may be above or below current expenses. The positive gross and net margins summarized in this paper suggest that TELRIC, as interpreted and implemented by state regulatory commissions, is typically above embedded costs.

An alternate validation is provided in a recent decision by the Massachusetts Department of Telecommunications and Energy. ${ }^{79}$ Under the Department's assumptions, the difference in retail and wholesale costs for a Total Service Resale ("TSR") line is $25.51 \% .{ }^{80}$ For a TSR line, however, the BOC incurs costs that are not born for a UNE$P$ line. For example, access charges are paid by the CLEC for a UNE-P line, whereas those charges are paid by the ILEC for a TSR line. Also, operator services may be provided by a third-party vendor for UNE-P lines, so these costs may be avoided for UNE-P even though incurred for a TSR. If access charges and operator service expenses are properly considered avoided for a UNE-P customer, then the avoided retail costs in Massachusetts are $46.5 \%$ of retail expenses. Including operator services lowers the difference to $41.3 \%$. From Table 5, the wholesale costs computed using the methodology described in this paper renders a difference between wholesale and retail expenses for Verizon of $47.3 \%$. Obviously, these wholesale-retail cost differences are very similar, and provide further validation of the reasonableness of our calculations and estimates.

Finally, prices in competitive markets tend to cost and the goal of TELRIC was to mimic the competitive price. As a consequence, the relationship of TELRIC to "cost" could be assessed if TELRIC-based prices could be compared to competitive prices for analogous services. Since unbundled elements are typically those components

79 Order on Verizon Massachusetts' Compliance Filing, D.T.E. 01-20-Part A-B (May 29, 2003).

80 Id. at 26. The Department ordered a TSR discount of $25.51 \%$, whereas Verizon proposed a TSR discount of $22 \%$. Id. at 16 .

81 This price is computed using a fixed fee of $\$ 711.09$ per circuit and a mileage charge of $\$ 15.21$ per mile. Letter from Henry Hultquist, Worldcom, Inc. to Marlene Dortch, Federal Communications Commission, at Attach. (Oct. 29, 2002) (on file with authors). Mileage of 185 miles is based on the distance between the airports of the two cities. See of the network subject to monopoly conditions, such comparisons are rare. However, some analogies are available. For example, consider the relative prices of a DS3 circuit (a high capacity circuit) between New York City and Albany, New York. At the Verizon-New York TELRIC-based prices, this circuit would cost about $\$ 3,500$ per month. ${ }^{81}$ This same circuit, however, would cost only about $\$ 2,200$ if purchased from a competitive provider. ${ }^{82}$ This same circuit, however, would cost only about $\$ 2,200$ if purchased from a competitive provider. This relationship between a competitive price and TELRIC was recently affirmed by William C. Deere, a former employee and consultant for SBC. In a recent deposition, Mr. Deere acknowledged "They may be better than TELRIC [prices] if there are [ ] competitive facilities available.... If there's competition there, it's probably lower than our rates." 83 These examples provide corroborating evidence that TELRIC may be above the "actual" cost of providing unbundled elements.

\section{CONCLUSION}

Recent reports on the financial consequences of UNE-P sales for Bell Operating Companies have drawn additional attention to long-standing complaints by the BOCs that such sales are confiscatory and amount to subsidized competition. Of course, no one expects incumbent firms to support any sort of unbundling at prices that a competitor would be willing to pay. Nevertheless, there is an important distinction between mandated unbundled element sales that are unwelcome, and mandated sales that actually threaten the viability of the incumbent providers. The BOCs' complaints establish that unbundled element sales are unwelcome, but not that they are, in any relevant sense, "below cost."

A number of recent financial studies find that mandated UNE-P sales produce losses for the in-

Convertit.com, at http://www.converit.com. This calculation is illustrative, since this circuit could not actually be purchased as an unbundled element because it crosses LATA boundaries.

82 The competitive price was provided by BANDWIDTH MARKET, LTD., at http://www.bandwithmarket.com.

83 Deposition of William C. Deere, In re Implementation of the Federal Communications Commission's Triennial Review Regarding Local Circuit Switching in the Mass Market, Ohio Public Utilities Commission, Case No. 03-2040-TP-COI (Nov. 19, 2003), at 73. 
cumbents, and that these losses, despite longstanding claims about the excessive profitability of long distance markets, are not offset through inregion, long distance operations permitted under the Section 271 process. ${ }^{84}$ The financial analyses by Merrill Lynch, UBS and others described in this paper, however, are designed specifically to provide investment advice and, as such, are not useful for evaluating the social impacts of required element sales. Indeed, from the investor's point-of-view, a firm that gained a monopoly might represent an excellent opportunity, although it is incorrect to argue from these premises that society should welcome such a development. On the other hand, financial analyses do serve a useful purpose, and the survival of the Bell companies is presumably a matter of concern for regulators and the public, as well as Wall Street.

This paper subjects the conclusions of these financial studies to careful scrutiny and finds that they are largely without merit. Errors in both the calculation of unbundled element revenues, and in the wholesale costs of providing unbundled elements, are identified. Using actual payments by a representative CLEC, we find that revenues ordinarily reported in financial analyses are substantially understated. These understatements arise from several sources, including omission of certain nonrecurring charges, incorrect assumptions on the mix of loops purchased by competitors, and so on.

On the cost side, the publicly available ARMIS

84 Telecommunications Act of $1996 \$ 271$.

85 See H. R. ReP. No. 104-458, preamble (1996) (stating data can be used to construct measures of currents costs for wholesale element sales in a manner conceptually consistent with Bell protestations on these matters. While such costs are not economic costs, neither are they hypothetical. Instead, they represent costs incurred by the incumbents and, therefore, are relevant for financial analyses of the type under discussion. We carefully obtain realistic cost figures usable for financial analyses. We do not use TELRIC costs, nor do we seek to identify the costs of efficient forwardlooking network operations.

Our analysis suggests that positive gross and net margins are the rule when costs and revenues are aggregated to the level of the BOC. Even the inclusion of depreciation and a return to capital does not materially alter this conclusion-UNE-P is profitable to the BOCs.

Concerns over the profitability of unbundled element sales reflect a widespread recognition that such sales are less profitable than an indefinite retention of monopoly power. While the BOCs would surely be better off if they were not required to accommodate competition (for a variety of reasons), the emergence of effective competition in local markets is the primary policy goal of the Telecommunications Act of $1996 .{ }^{85}$ Regulatory actions that derail the unbundling process are tantamount to abandonment of the Act's goals. In fact, declining margins are a hallmark of competition and a signal that the Act's implementation is promoting the desired effects.

that the bill is "to provide for a pro-competitive, de-regulatory national policy framework ..." "). 